\title{
EFFECTS OF POTASSIUM AND WATER AVAILABILITY ON WATER USE EFFICIENCY OF COMMON BEAN (PHASEOLUS VULGARIS L.)
}

\author{
W.A.J.M. DE COSTA* and L.P. LIYANAGE \\ Department of Crop Science, Faculty of Agriculture, University of Peradeniya, Peradeniya.
}

(Received: 16 September 1996;accepted: 5 October 1997)

\begin{abstract}
Water use efficiency (WUE), i.e. biomass produced per unit of water transpired, is an important criterion that determines crop productivity, especially under drought. As WUE is determined by the ratio between photosynthetic and transpiration rates, stomatal conductance $\left(\mathrm{g}_{\mathrm{s}}\right)$ is expected to play a major role in determining WUE. The effects of two factors that may influence $g_{s}$, namely, different levels of potassium $(\mathrm{K})$ and water supply on WUE of different varieties of common bean (Phaseolus vulgaris L.) were tested. Two indoor pot experiments were done. Experiment 1 was done with low- $\mathrm{K}$ soil using a single variety. Experimental treatments were two levels of $K$ application, i.e. with $(+)$ and without (-) K application, and water regimes ( $75 \%$ and $55 \%$ of field capacity). The $+\mathrm{K}$ treatment had two applications of $\mathrm{K}_{2} \mathrm{SO}_{4}$ at $85 \mathrm{mg} /$ pot. Experiment 2 was done using 5 varieties in nutrient solutions containing two levels of $\mathrm{K}^{+}(0.4$ and $4 \mathrm{mM}$ ). Transpiration and biomass accumulation were measured by daily weighing and destructive sampling respectively. Both experiments showed that the different levels of $\mathrm{K}$ used did not cause a significant effect on WUE. However, WUE was significantly increased by water stress and significant varietal variation in WUE $\left(4.93-5.36 \mathrm{~g} \mathrm{~kg}^{-1}\right)$ was observed. It is argued that the absence of significant differences in WUE under different $K$ levels occurred because both photosynthesis and transpiration may not have been affected by K. Despite the reduced external $\mathrm{K}$ supply, the cytoplasmic $\mathrm{K}$ concentration may have been maintained at a high enough level to ensure adequate photosynthesis. This is supported by the absence of significant differences in total biomass between different $\mathrm{K}$ treatments. Although higher $\mathrm{K}$ levels may have increased $\mathrm{g}_{\mathrm{s}}$, transpiration may not have increased because of greater boundary layer resistance and decreased sensitivity of transpiration to $\mathrm{g}_{\mathrm{c}}$. Therefore, it is concluded that a factor that may cause a change in $g_{x}$ may not necessarily alter WUE. The need for detailed measurements of $g_{s}$, transpiration and photosynthetic rates is emphasized.
\end{abstract}

Key words: Bean, Phaseolus vulgaris, potassium, varieties, water stress, water use efficiency.

\section{INTRODUCTION}

Water use efficiency (WUE) is the amount of biomass produced per unit of water used by a crop through transpiration. ${ }^{1}$ WUE is one of the parameters through which crop yields could be increased, especially in water-limited environments. ${ }^{2}$ Therefore, WUE is a promising trait which could be used in breeding for drought tolerance. ${ }^{3}$ At the single leaflevel, instantaneous WUE is the ratio between rates

${ }^{*}$ Corresponding author. 
of net photosynthesis and transpiration. Since both these processes involve gas exchange through stomata, any factor affecting stomatal conductance could change WUE. ${ }^{4}$ The present paper investigates two such factors which are known to influence stomatal conductance, namely potassium $(\mathrm{K})$ and water availability. ${ }^{5,6}$

Literature shows conflicting results on the effects of $\mathrm{K}$ and generally of plant nutrients on WUE. In the field- or pot-grown plants at very low nutrient levels, increases of WUE have been observed with increased nutrient supply. ${ }^{7}$ However at medium to high nutrient levels, WUE has been independent of nutrient supply. ${ }^{8,9}$ Gas exchange measurements on single leaves have shown WUE to both increase ${ }^{10,11}$ and remain stable with increasing nutrient status. ${ }^{12}$ Although it is believed that increased $\mathrm{K}$ increases WUE, Walker \& Richards ${ }^{13}$ observed a single, strongly linear relationship between biomass and transpiration of potgrown Medicago sativa across a wide range of soil and plant $\mathrm{K}$ status going from severely deficient to adequate. This implied that WUE is insensitive to variation in $\mathrm{K}$ status.

Similarly, contrasting experimental evidence exists on the variation of WUE in response to different levels of water availability. Using a gas exchange model, Jones ${ }^{4}$ showed that increased stomatal resistance $\left(r_{s}\right)$ resulting from water stress caused an increase in instantaneous WUE except when the ratio of internal mesophyll resistance $\left(r_{i}\right)$ to leaf boundary layer resistance $\left(r_{i}\right)$ is below a certain critical value. Likewise, WUE of pot- and field-grown cowpea has been shown to increase with water stress. ${ }^{14}$ However, extensive reviews have concluded ${ }^{3,7}$ that it is not proven that WUE increases in response to drought over longer periods for field crops. The present paper investigated the above aspects using common bean which is an important vegetable legume in Sri Lanka. The objectives of the two experiments were to determine: (a) the effects of different regimes of $K$ and water application on WUE; (b) whether $\mathrm{K}$ and water had an interaction in influencing WUE since both could modify stomatal conductance $\left(\mathrm{g}_{\mathrm{s}}\right)$ which plays a central role in controlling WUE.

\section{METHODS AND MATERIALS}

\section{Experiment 1: Effects of $K$ and water regimes}

\section{Plant Culture}

The experiment was conducted from January to February, 1995 in a plant house at the Faculty of Agriculture, University of Peradeniya. Common bean plants (var. Topcrop) were grown in plastic pots $(20 \mathrm{~cm}$ tall and $18 \mathrm{~cm}$ cross-sectional diameter) containing $3.5 \mathrm{~kg}$ of air-dried soil. Two plants were grown in each pot. The initial exchangeable $\mathrm{K}$ content of the soil was measured by ammonium 
acetate extraction method ${ }^{15}$ using the flame photometer. The initial $\mathrm{K}$ content of the soil was found to be 15 ppm which fell within the 'very low' category in terms of $\mathrm{K}$ availability. ${ }^{16}$

\section{Experimental Design}

The experimental treatment structure was a $2 \times 2$ factorial, with two levels each of potassium and water availability. Two levels of potassium availability were established by applying $K$ at recommended rates $(+K)$ as basal and top dressings at 3 weeks after planting and witholding $K(-\mathrm{K})$ in basal and top dressings. The $+\mathrm{K}$ treatment received $85 \mathrm{mg} /$ pot of $\mathrm{K}$ in the form of $\mathrm{K}_{2} \mathrm{SO}_{4}$ at each dressing. Other fertilizer components, i.e. N (Urea) $102 \mathrm{mg} /$ pot and P (Triple Super Phosphatè) $60 \mathrm{mg} /$ pot, were applied in recommended dosages.

Two levels of water availability were established by differential application of water. The well-watered (W1) treatment was maintained at $75 \%$ of field capacity of the soil which was determined from initial measurements. The waterstressed (W2) treatment was maintained at 55\% field capacity. The water levels were maintained by daily weighing and subsequent application of measured amounts of water. The four treatment combinations were laid out in a randomized complete block design with 12 replicates. Crop management was done as described. ${ }^{17}$

\section{Measurements}

Daily transpiration rates were measured by weight measurements and a subsequent computation of the water balance. Biomass production was measured by destructive sampling at 15, 30 and 45 days after sowing (DAS). Eight plants were harvested from each treatment on a given sampling date. Both roots and shoots were harvested. Dry weights were measured after oven drying at $80^{\circ} \mathrm{C}$ for at least 48 hours. The $\mathrm{K}$ content of plant tissue was measured at 30 and 45 DAS using the dry ash method. ${ }^{18}$ Leaf area was measured by an automatic leaf area meter.

\section{Calculations and Data Analysis}

All calculations and data analysis were done essentially as described ${ }^{17}$ with the following differences. Water use efficiency was calculated for both the entire period (i.e. 0 - 45 DAS) and for the three time periods between adjacent growth harvests using simple linear regression. Relative growth rate (RGR), net assimilation rate (NAR) and specific leaf area (SLA) were calculated as described in de Costa and Ariyawansha. ${ }^{17}$ Correlation analysis was used to examine interrelationships between these parameters. 
Experiment 2: Effects of $K$ on different varieties

\section{Plant Culture}

The experiment was conducted from August - September, 1995 in a plant house at the Institute of Plant Nutrition, University of Hohenheim, Germany. Common bean plants were grown in $2.5 \mathrm{l}$ plastic pots containing the following nutrient solution: $0.75 \mathrm{mM} \mathrm{MgSO} ; 0.2 \mathrm{mM} \mathrm{KH}_{2} \mathrm{PO}_{4} ; 0.01 \mathrm{mM} \mathrm{KCl} ; 4 \mathrm{mM}$ $\mathrm{Ca}\left(\mathrm{NO}_{3}\right)_{2} ; 0.1 \mathrm{mM}$ Fe-EDTA; $0.01 \mathrm{mM} \mathrm{H}_{3} \mathrm{BO}_{4} ; 2 \times 10^{-3} \mathrm{mM} \mathrm{MnSO}_{4} ; 1 \times 10^{-3} \mathrm{mM}$

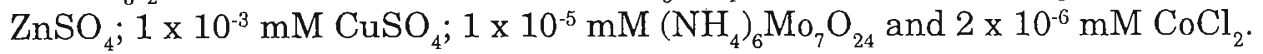

\section{Experimental Design}

Two levels of $\mathrm{K}$ supply were established by adding different amounts of $\mathrm{K}_{2} \mathrm{SO}_{4}$ to the common components of the nutrient solution (Table 1). Seeds of 5 varieties (i.e. Brilliant, Wade, Contender, Cherokee Wax and Top Crop) were germinated in a sand-vermiculite medium and the seedlings were transferred to the nutrient solutions at $1 / 5$ of full concentration at 7 days after sowing. Concentration of the nutrient solution was increased to $1 / 2$ of full concentration after 2 days and to full concentration after a further 2 days. The nutrient solution was replaced 3 times per week throughout the experimental period. Transpiration was measured by weighing the pots at the time of replacing the nutrient solution. Initial root and shoot dry weights were determined when seedlings were transferred to the nutrient solution, i.e. 7 days after germination. The ten $K x$ variety treatment combinations were laid out in a completely randomized design with 3 replicate pots per treatment. Each pot contained 4 plants.

Table 1: Different Potassium (K) Treatments.

Potassium Level $\quad \mathrm{K}^{+}$Concentration $(\mathrm{mM}) \quad \mathrm{K}_{2} \mathrm{SO}_{4}$ Concentration $(\mathrm{mM})$

High $\mathrm{K}^{+}$

Low $\mathrm{K}^{+}$
4

0.4
2

0.1

\section{Harvesting}

All plants were harvested at 24 days after germination. Root and shoot dry weights were determined by oven-drying. On the day of harvesting, leaf water potential $(\psi)$ of the youngest fully-expanded leaf of each plant was measured by the pressure chamber. ${ }^{19}$ 


\section{RESULTS}

\section{Experiment 1: Effects of $K$ and water regimes}

\section{Tissue K Content}

On both days of measurement and in both water regimes, the plants to which $\mathrm{K}$ was applied had higher tissue $K$ contents (Table 2) than those which did not receive any $\mathrm{K}$ fertilizer.

Table 2: Tissue $\mathrm{K}$ concentration at different levels of $\mathrm{K}$ application and water availability.

\begin{tabular}{ccccc}
\hline $\begin{array}{c}\text { Date of } \\
\text { Measurement } \\
\text { (Days after planting) }\end{array}$ & \multicolumn{2}{c}{$\begin{array}{c}75 \% \text { of } \\
\text { Field Capacity }\end{array}$} & \multicolumn{2}{c}{$55 \%$ of Field Capacity } \\
\cline { 2 - 5 } & $+\mathrm{K}$ & $-\mathrm{K}$ & $+\mathrm{K}$ & $-\mathrm{K}$ \\
\hline 30 & 1.20 & 0.81 & 1.16 & 0.76 \\
45 & 1.51 & 0.81 & 1.66 & 0.94 \\
\hline
\end{tabular}

\section{Mean water use efficiency $\left(\mathrm{WUE}_{\mathrm{m}}\right)$}

Dry matter accumulation increased linearly with cumulative transpiration in all four water $\mathrm{x} \mathrm{K}$ treatment combinations (Fig. 1) over the entire period of the experiment. As expected, the water-stressed plants had significantly greater $(\mathrm{p}<0.05)$ levels of $\mathrm{WUE}_{\mathrm{m}}$ at both levels of $\mathrm{K}$ as compared to the well-watered plants. However, there was no significant difference in the $\mathrm{WUE}_{\mathrm{m}}$ under different levels of $\mathrm{K}$. This was true for both water regimes.

\section{Periodic water use efficiency $\left(W_{\mathrm{W}}\right)$}

WUE $_{p}$ showed a similar variation pattern with plant age in all water $\mathrm{x} K$ treatment combinations (Fig. 2). After the initial 15-day period where WUE was significantly higher (6.71-8.19 $\left.\mathrm{g} \mathrm{kg}^{-1}\right)$, there was a decline during the second 15day period (1.41-2.49 $\mathrm{g} \mathrm{kg}^{-1}$ ). During the third 15-day period, which coincided with the beginning of pod filling, WUE increased to some extent (2.36-3.15 $\mathrm{g} \mathrm{kg}^{-1}$ ) as compared to the preceding period. 


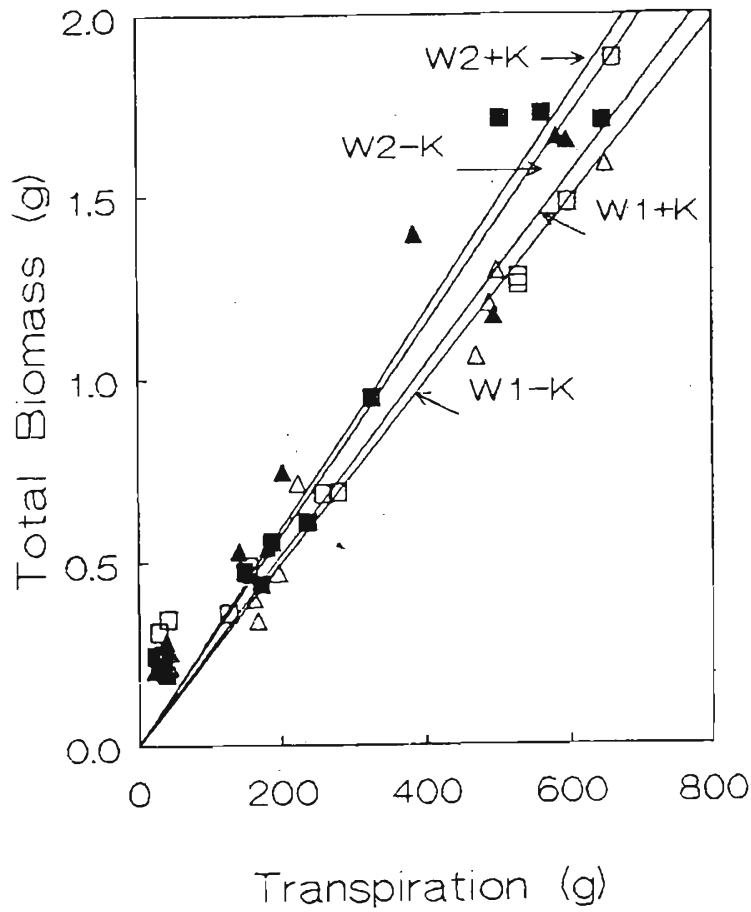

Figure 1: Relationship between cumulative transpiration ('T) and biomass accumulation $(W)$ under different potassium and water regimes. Open symbols: wellwatered treatment $\left(\mathrm{W}_{1}\right)$; Closed symbols: water-stressed treatment $\left(\mathrm{W}_{2}\right)$. Triangles: -K; Squares: $+\mathrm{K}$. Lines indicate regressions: $\mathrm{W}_{1}-\mathrm{K}: \mathrm{W}=2.475( \pm 0.108) \mathrm{T}\left(\mathrm{R}^{2}=\right.$ $0.98) ; \mathrm{W}_{1}+\mathrm{K}: \mathrm{W}=2.586( \pm 0.113) \mathrm{T}\left(\mathrm{R}^{2}=0.98\right) ; \mathrm{W}_{2}-\mathrm{K}: \mathrm{W}=2.886( \pm 0.142) \mathrm{T}\left(\mathrm{R}^{2}=0.97\right.$; $\mathrm{W}_{2}+\mathrm{K}: \mathrm{W}=2.953( \pm 0.114) \mathrm{T}\left(\mathrm{R}^{2}=0.98\right.$.

\section{Relationships of WUE ${ }_{p}$ with RGR, NAR and SLA}

WUE had significant linear relationships with RGR (Fig.3) and NAR (Fig. 4). Both relationships did not differ significantly between different $K$ levels. However, there was no significant relationship between WUE $\mathrm{p}_{\mathrm{p}}$ and SLA (Fig. 5).

\section{Experiment 2: Effects of $K$ on different varieties}

\section{Leaf water potential $(\psi)$}

Different levels of $\mathrm{K}$ supply had a significant effect on $\psi$ of cultivars 'Brilliant' and 'Top crop' with the high K treatment showing a significantly lower $(\mathrm{p}<0.05)$ $\psi$ than low K treatment (Table 3 ). There was a significant variety $x$ Kinteraction on $\psi$. All varieties had lower $\psi$ levels under high K except for the variety 'Wade' in which there was no significant difference. 


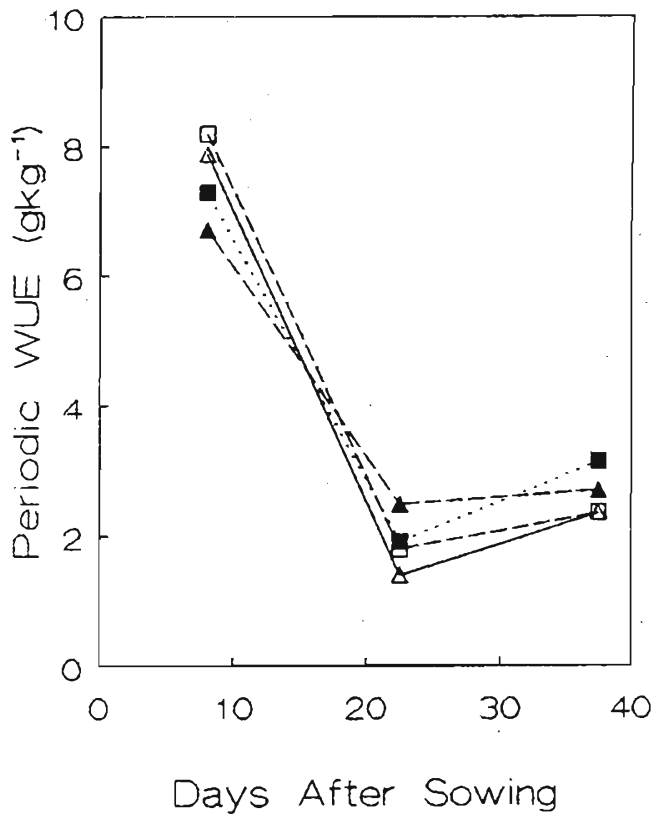

Figure 2: Variation of periodic WUE with time for different varieties under two water regimes. Symbols are the same as in Fig. 1.

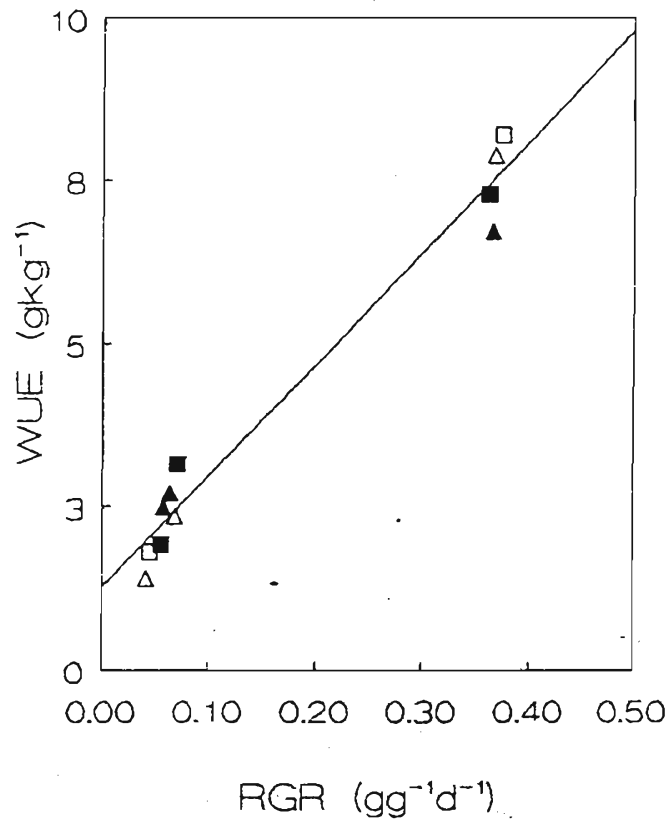

Figure 3: Relationship between WUE and RGR for different varieties under two water regimes. Symbols are the same as in Fig. 1.

Regression equation: $\mathrm{WUE}=1.27+17.08(\mathrm{RGR}) .\left(\mathrm{R}^{2}=0.97\right)$. 


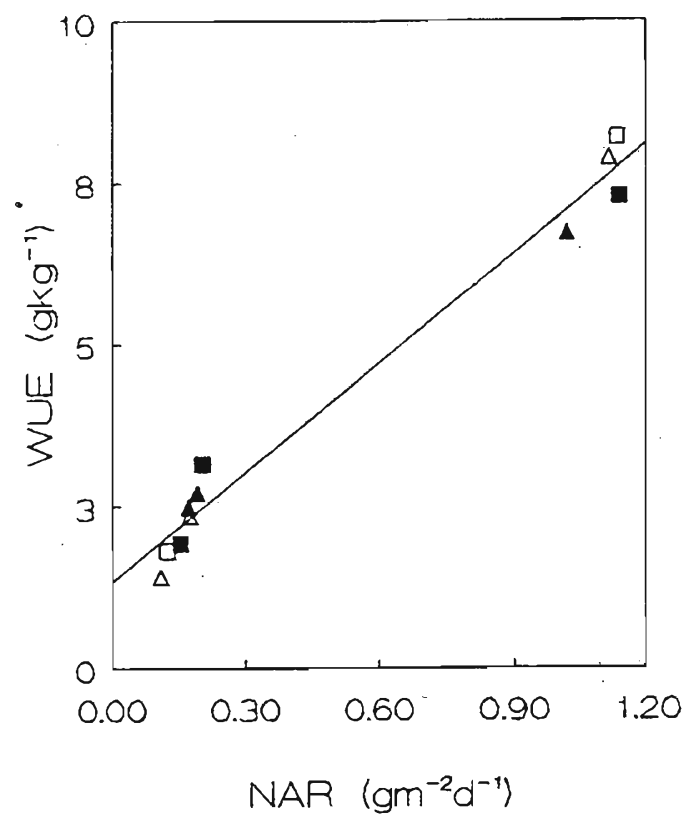

Figure 4: Relationship between WUE and NAR for different varieties under two water regimes. Symbols are the same as in Fig. 1.

Regression equation: $\mathrm{WUE}=1.33+5.63(\mathrm{NAR}) .\left(\mathrm{R}^{2}=0.98\right)$.

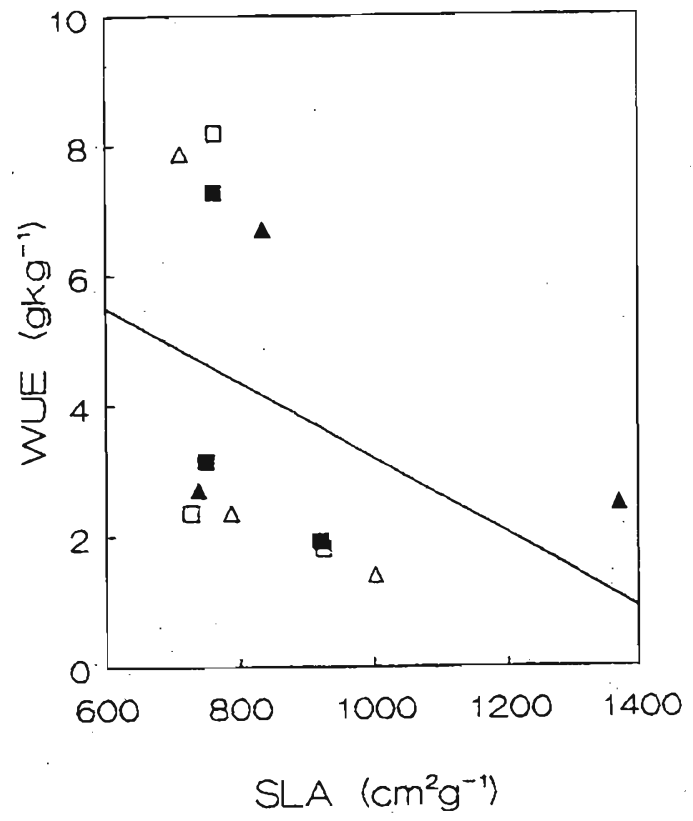

Figure 5: Relationship between WUE and SLA for different varieties under two water regimes. Symbols are the same as in Fig. 1.

Regression equation: WUE $=8.96-0.0058$ (SLA). $\left(\mathrm{R}^{2}=0.08\right)$ 
Table 3: Effect of $\mathbf{K}$ on leaf water potential $(\psi)$ of different varieties of common bean.

\begin{tabular}{lccc}
\hline Variety & \multicolumn{3}{c}{$\psi\left(\mathrm{x} 10^{-1} \mathrm{MPa}\right)$} \\
\cline { 2 - 4 } & $0.4 \mathrm{mM}$ & $4 \mathrm{mM}$ & LSD (p=0.05) \\
\hline Brilliant & 2.1 & 3.1 & 0.6 \\
Wade & 2.5 & 2.3 & 0.7 \\
Contender & 2.2 & 2.8 & 0.8 \\
Cherokee Wax & 1.8 & 2.7 & 0.9 \\
Top Crop & 1.9 & 3.1 & 1.1 \\
Mean & 2.1 & 2.8 & 0.3 \\
LSD (p=0.05) & 0.4 & 0.7 & \\
\hline
\end{tabular}

\section{Water use efficiency (WUE)}

Biomass accumulation during the 17-day period (i.e. 7-24 days after germination) of measurement showed a significant linear relationship with transpiration under both levels of $\mathrm{K}$ supply (Fig. 6). Once again, there was no significant difference between WUE of the two K levels. Varieties 'Top Crop' and 'Contender' had higher levels of WUE $\left(5.28-5.36 \mathrm{~g} \mathrm{~kg}^{-1}\right)$ than the rest $\left(4.93-4.99 \mathrm{~g} \mathrm{~kg}^{-1}\right)$ (Table 4).

Table 4: Water use efficiency (WUE) of different varieties (averaged across K levels).

\begin{tabular}{lcc}
\hline Variety & WUF $\pm \mathrm{se}\left(\mathrm{g} \mathrm{kg}^{-1}\right)$ & $\mathrm{R}^{2}$ \\
\hline Brilliant & $4.99 \pm 0.16$ & 0.98 \\
Wade & $4.93 \pm 0.21$ & 0.97 \\
Contender & $5.28 \pm 0.17$ & 0.96 \\
Cherokee Wax & $4.97 \pm 0.13$ & 0.95 \\
Top Crop & $5.36 \pm 0.15$ & 0.98 \\
\hline
\end{tabular}




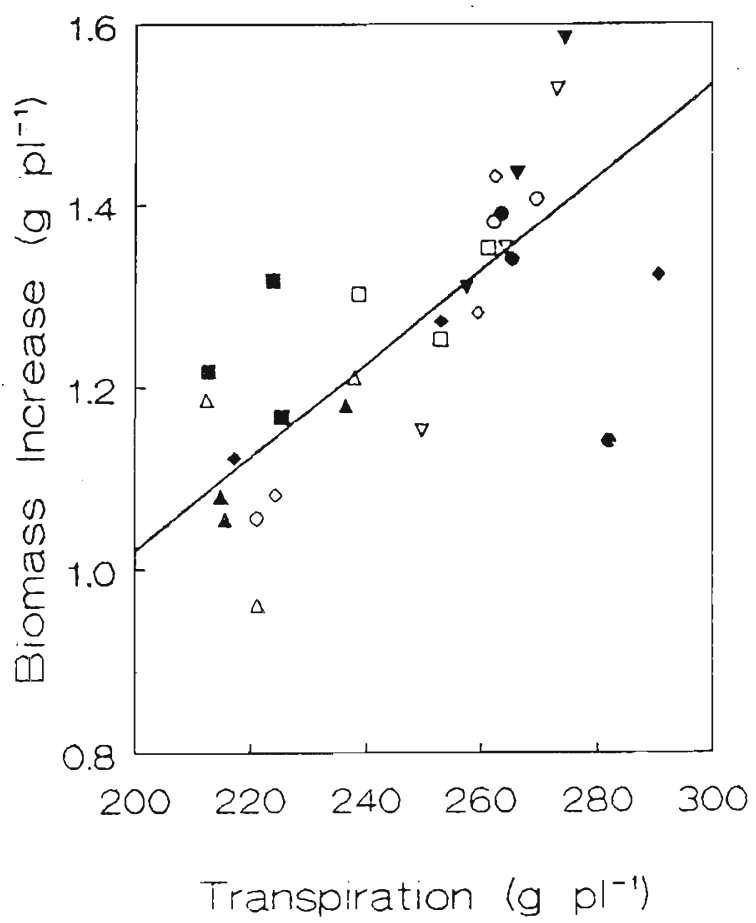

Figure 6: Relationship between cumulative transpiration (T) and biomass accumulation (W) of different varieties under two potassium regimes. Open symbols: Low $\mathrm{K}^{+}(0.4 \mathrm{mM})$; Closed symbols: High $\mathrm{K}^{+}(4 \mathrm{mM}) . \Delta$ Brilliant; $\mathrm{O}$ Wade; $\nabla$ Contender; Cherokee Wax; $\square$ Top Crop. Lines indicate regressions for the two K levels: Low $\mathrm{K}^{+}$: W $=5.113( \pm 0.089) \mathrm{T}\left(R^{2}=0.98\right) ;$ High $\mathrm{K}^{+}: \mathrm{W}=5.1( \pm 0.013) \mathrm{T}\left(\mathrm{R}^{2}=0.98\right)$.

\section{DISCUSSION}

The significant inter-varietal differences in WUE (experiment 2) and the significantly higher WUE under water stress (experiment 1) observed in the present experiments confirmed the earlier results of de Costa \& Ariyawansha. ${ }^{17}$ The relatively lower leaf water potential in the high $\mathrm{K}^{+}$treatment was in agreement with the observations of Mengel \& Arneke $^{20}$ for older leaves of common bean under comparable levels of $\mathrm{K}^{+}$supply. It is possible that the significantly higher $\mathrm{K}^{+}$level in the high $\mathrm{K}^{+}$treatment decreased the leaf osmotic potential ${ }^{5,21}$ to initiate a greater pressure potential as observed by Mengel \& Arneke..$^{20}$ Results of both experiments clearly showed that the difference in the $\mathrm{K}^{+}$supply used did not have a significant effect on WUE. This agreed with the results obtained by Walker \& Richards ${ }^{13}$ for Medicago sativa and Kabaki et al..$^{22}$ for rice. However, the present results contradict the common, though not unequivocally-proven, opinion that shortage of $\mathrm{K}^{+}$reduces the WUE. ${ }^{5,23}$ The above opinion is based on the perceived effects of $\mathrm{K}^{+}$on transpiration and photosynthesis. 
However, evidence could be found from literature to show that variation of $\mathrm{K}^{+}$ supply may not always cause significant changes in WUE.

A key question here is the effect of $\mathrm{K}^{+}$on photosynthesis. Although photosynthesis was expected to be lower under low $\mathrm{K}^{+},{ }^{24}$ several pieces of evidence exist to show that this may not have been the case in the present study. Firstly, there was no significant decrease in the total dry weight between plants having higher or lower $\mathrm{K}^{+}$levels. Secondly, even at the low $\mathrm{K}^{+}$levels used in the present experiments, the plants did not show $\mathrm{K}$ deficiency symptoms. Although the tissue $\mathrm{K}^{+}$content of the low $\mathrm{K}^{+}$plants was lower, it may still have been above the critical $\mathrm{K}^{+}$concentrations. ${ }^{25}$ Thirdly, evidence exists to show that despite reduced levels of $\mathrm{K}^{+}$supply (and consequently lower levels of tissue $\mathrm{K}^{+}$), the cytoplasmic $\mathrm{K}^{+}$concentrations could be maintained at a high enough level so that plant metabolism including photosynthesis may be maintained at higher levels until severe shortages occur. ${ }^{26-28}$

Another key point in the determination of WUE under different $\mathrm{K}$ levels is the effect of $\mathrm{K}$ on stomatal conductance and consequently on transpiration. Although plants having higher $\mathrm{K}^{+}$levels are generally expected to have greater stomatal conductance ${ }^{29}$ and hence greater transpiration, there is evidence that both the above may not always be true. Hsiao \& Lauchli ${ }^{5}$ observed substantial variation in stomatal responses to variation in $\mathrm{K}^{+}$availability in different species and concluded that although stomatal conductance was lower under low $\mathrm{K}^{+}$ levels this may occur only at an advanced stage of $K$ deficiency. Since deficiency symptoms were not shown in either of the present experiments, it is doubtful whether the different $\mathrm{K}^{+}$levels really caused significant variations in stomatal conductance. Hsiao \& Lanchli ${ }^{5}$ further concluded that a reduction in stomatal conductance under low $\mathrm{K}^{+}$may be a consequence rather than cause of reduced photosynthesis and dry matter production. Since significant differences in growth were not observed in the present experiments, it is highly likely that there were no significant differences in stomatal conductance.

Even if significant variation in stomatal conductance did occur, it doesn't necessarily follow that transpiration is also higher under greater stomatal conductance. Jarvis \& McNanghton ${ }^{30}$ have shown that transpiration is proportional to stomatal conductance only when mass and energy exchanges between the leaf and the surrounding atmosphere is efficient and hence when leaf temperature is approximately equal to the air temperature. However, in the present experiments, plants were grown in a glasshouse. The low level of air circulation therein and the large leaves of hydroponically-grown bean plants would have resulted in high boundary layer resistances around the leaves. This will have prevented efficient exchange of mass and energy. Under such. conditions, leaf temperature can diverge markedly from air temperature and transpiration could be mainly energy dependent and insensitive to variations in 
stomatal conductance. This is highly likely to have happened in the present experiments. The absence of significant differences in transpiration between different $\mathrm{K}^{+}$levels confirms it.

Therefore, although the absence of significant differences in WUE in the present experiments does not agree with the commonly-held though unsubstantiated opinion, phenomena outlined in the above discussion amply demonstrate the possibility of both photosynthesis and transpiration, and hence WUE, not being significantly affected by the different $\mathrm{K}$ levels used in the present experiments. More detailed experimentation is needed to confirm the above possibility.

\section{References}

1. Fischer R.A. \& Turner N.C. (1978). Plant productivity in the arid and semiarid zones. Annual Review of Plant Physiology 29: 277-317.

2. Passioura J.B. (1986). Resistance to drought and salinity: avenues for improvement. Australian Journal of Plant Physiology 13: 191-201.

3. Ludlow M.M. \& Muchow R.C. (1990). A critical evaluation of traits for improving crop yields in water-limited environments. Advances in Agronomy 43: 107-153.

4. Jones H.G. (1976). Crop characteristics and the ratio between assimilation and transpiration. Journal of Applied Ecology 13: 605-622.

5. Hsiao T.C. \& Lauchli A. (1986). Role of potassium in plant-water relations. In: Advances in Plant Nutrition, Vol. 2. (Eds. B. Tinker \& A. Lauchli). pp. 281-311. Praeger, New York.

6. Turner N.C. (1986). Crop water deficits: a decade of progress. Advances in Agronomy 39: 1-51.

7. Tanner C.B. \& Sinclair T.R. (1983). Efficient water use in crop production: research or re-search? In: Limitations to efficient water use in crop production. (Eds. H.M. Taylor, W.R. Jordan \& T.R. Sinclair). pp. 1-27. American Society of Agronomy.

8. De Wit C.T. (1958). Transpiration and crop yields. Verslagen van Landbouwkundige Onderzoekingen. No. 64.6, Institute for Biological and Chemical Research on Field Crops and Herbage, Wageningen. 88 pp. 
9. Arkley R.J. (1963). Relationships between plant growth and transpiration. Hilgardia 34: 559-584.

10. Wong S.C. (1979). Elevated atmospheric partial pressure of $\mathrm{CO}_{2}$ and plant growth. I. Interactions of nitrogen and photosynthetic capacity in $\mathrm{C}_{3}$ and $\mathrm{C}_{4}$ plants. Oecologia 44: 68-74.

11. Von Caemmerer S. \& Farquhar G.D. (1981). Some relationships between biochemistry of photosynthesis and the gas exchange of leaves. Planta 153: 376-387.

12. Goudriaan J. \& Van Keulen H. (1979). The direct and indirect effects of nitrogen shortage on photosynthesis and transpiration in maize and sunflower. Netherlands Journal of Agricultural Science 27: 227-234.

13. Walker G.K. \& Richards J.E. (1984). Transpiration efficiency in relation to nutrient status. Agronomy Journal 77: 263-269.

14. Hebbar K.B., Sashidhar V.R., Udayakumar M., Devendra R. \& Nageswara Rao R.C. (1994). A comparative assessment of water use efficiency in groundnut (Arachis hypogaea) grown in containers and in the field under water-limited conditions. Journal of Agricultural Science, Cambridge 122: 429-434.

15. Knudson D., Peterson G.A. \& Pratt P.F. (1982). Lithium, sodium and potassium. In: Methods of soil analysis. Part 2. 2nded. (Ed. A.L. Page). pp. 225-246. Soil Science Society of America, Madison, Wisconsin, USA.

16. Black C.R. (1967). Soil-plant relationships. John Wiley, New York. 792 pp.

17. de Costa W.A.J.M. \& Ariyawansha S.K. (1996). Effects of water stress on water use efficiency of different varieties of common bean (Phaseolus vulgaris L.). Journal of the National Science Council of Sri Lanka 24(4): 253-266.

18. Davidescu D. \& Davidescu V. (1982). Evaluation of fertility by plant and soil analysis. Abacus Press, U.K. 560 pp.

19. Scholander P.F., Hammel H.T., Bradstreet E.D. \& Hemmingsen E.A. (1965). Sap pressure in vascular plants. Negative hydrostatic pressure can be measured in plants. Science 148: 339-346. 
20. Mengel K. \& Arneke W.W. (1982). Effect of potassium on the water potential, the pressure potential, the osmotic potential and cell elongation in leaves of Phaseolus vulgaris. Physiologia Plantarum 54: 402-408.

21. Lindhauer M.G. (1989). The role of $\mathrm{K}^{+}$in cell extension, growth and storage of assimilates. In: Methods of K-research in plants. Proceedings of the 21 st Colloquium of the International Potash Institute. pp. 161-187. International Potash Institute, Bern, Switzerland.

22. Kabaki N., Saka H. \& Akita S. (1979). Effects of nitrogen, phosphorous and potassium deficiencies on photosynthesis and RUBP carboxylase-oxygenase activities in rice plants. Japanese Journal of Crop Science 48: 378-384.

23. Nelson W.L. (1980). Interactions of potassium with moisture and temperature. In: Potassium for agriculture - a situation analysis. pp. 109-119. Potash and Phosphate Institute, Atlanta, Georgia.

24. Peaslee D.E. \& Moss D.N. (1966). Photosynthesis in K- and Mg-deficient maize (Zea mays L.) leaves. Soil Science Society of America Proceedings 30: 220-223.

25. Leigh R.A. \& Wyn Jones R.G. (1984). A hypothesis relating critical potassium concentrations for growth to the distribution and functions of this ion in the plant cell. New Phytologist 97: 1-13.

26. Wyn Jones R.G., Brady C.J. \& Speirs J. (1979). Ionic and osmotic relations in plant cells. In: Recent advances in the biochemistry of cereals. (Eds. D.C. Laidman \& R.G. Wyn Jones). pp. 63-103. Academic Press, New York.

27. Wyn Jones R.G. \& Pollard A. (1983). Proteins, enzymes and inorganic ions. In: Encyclopedia of plant physiology, New Series, Vol. 15B. (Eds. A. Lauchli \& R.L. Bieleski). pp. 528-562. Springer-Verlag, Berlin.

28. Leigh R.A. \& Wyn Jones R.G. (1986). Cellular compartmentation in plant nutrition: the selective cytoplasm and the promiscuous vacuole. In: Advances in Plant Nutrition, Vol. 2. (Eds. B. Tinker \& A. Lauchli). pp. 259-279. Praeger, New York.

29. Fischer R.A. \& Hsiao T.C. (1968). Stomatal opening in isolated epidermal strips of Vicia faba. II. Response to $\mathrm{KCl}$ concentrations and the role of potassium absorption. Plant Physiology 43: 1953-1958.

30. Jarvis P.G. \& McNaughton K.G. (1986). Stomatal control of transpiration: scaling up from leaf to region. Advances in Ecological Research 15: 1-49. 